\title{
The new Dolgarrog memorial
}

S. Morris BSC (Hons), IEng, CWEM, MCIWEM Reservoirs Supervising Engineer, Natural Resources Wales, UK

A. R. Davies BEng (Hons), CEng, CEnv, MICE

Reservoirs Supervising Engineer, Natural Resources Wales, UK
S. J. Shakespeare CEng, MICE, CEnv, MCIWEM

Dam Safety Engineering Manager (North), Dwr Cymru Welsh Water, UK

(corresponding author: stephen.shakespeare@dwrcymru.com)

The Dolgarrog Dam Disaster claimed the lives of 16 people and led to the introduction of current UK reservoir safety legislation. This paper is a summary of the events of that fatal night in 1925, the legislation that followed and an account of the recent improvement works carried out to the memorial site in the village of Dolgarrog.

\section{The disaster}

It was a night that changed the landscape of a small North Wales village forever and brought about new legislation that changed the way reservoirs in the United Kingdom are regulated.

On the night of November, the $2^{\text {nd }}, 1925$ Llyn Eigiau Reservoir failed releasing $4500000 \mathrm{~m}^{3}$ of water (Figure 1). The $1200 \mathrm{~m}$ long $11 \mathrm{~m}$ high concrete dam was built in 1911 to supply water for the aluminium works at Dolgarrog. The original contractor pulled out of the construction, alleging corner cutting. Following $660 \mathrm{~mm}$ of rain in just $5 \mathrm{~d}$, the dam failed due to insufficient foundations and the use of poor quality materials.

At about 20:45 GMT, the water from the reservoir flooded downstream, overtopping the Coedty dam, which held $350000 \mathrm{~m}^{3}$. This then failed, releasing up to $4850000 \mathrm{~m}^{3}$ of water down the valley, taking with it thousands of tonnes of boulders, mud and debris into Dolgarrog.

The flood killed ten adults and six children in the Conwy Valley community, the loss of life could have been far greater, as many of the villagers were watching a film in the village hall situated on higher ground.

Within $20 \mathrm{~min}$, the water had flooded across the main road, swept away houses on Machno Terrace, the church, church house, sweet shop, butcher's and water mains. The water then inundated the aluminium works causing both furnaces to explode, which was witnessed by the local vicar who raised the alarm. He managed to save every man at the works, entering the deep water to save the remaining few who were stranded. If he had not been a man of significant stature at $6 \mathrm{ft} 7 \mathrm{in}$, the death toll could have been many more.

The flow of water from the dams did not cease until mid-morning the following day, cows were seen hanging from the trees and the aluminium works were submerged under $1.5 \mathrm{~m}$ of mud. Sightseeing trips were organised and visitors came from across the country to see the aftermath.

\section{Legislation}

Almost a century ago, 16 people lost their lives when the release of water from an impounding reservoir flowed down to the village of Dolgarrog in the Conwy Valley. The sudden release of water was from the failure of a poorly constructed, slender concrete dam founded on poor substrate.

It is the events from this disaster that helped shape reservoir safety legislation as we know it today. Occurrences from previous decades where there were numerous dam failures in the United Kingdom, which also led to loss of life prompted no safety bill or change in legislation to prevent such disasters occurring again. Dam disasters at Bilberry, Dale Dyke and Skelmorlie with a total loss of 268 lives did little to prompt action from parliament at the time with World Wars being a priority for the government.

The Dolgarrog disaster remains one of the worst disasters in Welsh history alongside Aberfan, The Universal Colliery disaster and many other mining disasters. The great irony with Dolgarrog is that owners of the dam knew that the dam was

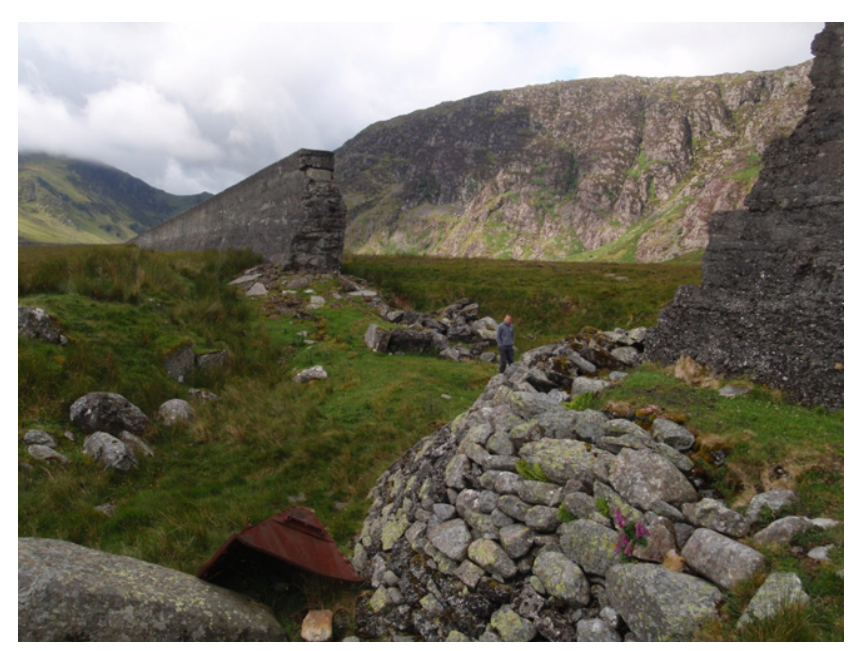

Figure 1. Llyn Eigiau today 
poorly constructed, founded on poor ground and was hastily built. Early warning signs of failure were also ignored by senior managers of the aluminium corporation company at the time. It was this failure to react to early signs of dam failure which has in modern times under legislation highlighted the need for reservoir undertakers to proactively risk assess, report on and react to safety considerations and protection of the public.

Unlike later in the century with the onset of television and live reporting at Aberfan as an example, the dam disasters of the last century were not televised like modern day disasters, which are very quickly shared on social media and news rooms. There are however plenty of photographs and black and white cine footage of the aftermath of Dolgarrog highlighting the devastation. It could be perceived as perverse that cine reels and photographs taken by individuals at the time give us engineers a glimpse of the scale of the disaster and gives us an understanding of the immediate aftermath of a dam failure and the suffering caused.

In the weeks and months following the disaster, public attention naturally turned to finding out what, and who was responsible for the failure of the Eigiau dam. Dam owners at the time denied they were aware of the deficiencies in its design and construction.

Within reservoir safety engineering circles it is widely known that Dolgarrog was instrumental in leading parliament to pass the Reservoirs (Safety Provisions) Act in 1930, which introduced laws on the safety of reservoirs. The 1930s Act has since been superseded by the 1975 Act. It must not be forgotten that previous pieces of legislation had been enacted to protect the public, namely the Water Works Clauses Act of 1863, this Act of parliament was not dam specific and did little to prevent failures or indeed improve the attitudes of dam owners towards public safety after this enactment.

The Sandeman letter to the Times on the 4 December 1925 following recent failures drew the government at the time into acknowledging that legislation was not fit for purpose to protect the public thus leading to the Reservoirs (Safety Provisions) Act 1930. Mr Sandeman drew the parliament select committee's attention to recommendations made by the Water Works Clauses Act and the reference made to the 'Periodic inspection of reservoirs that have become dangerous and allowed to decay'.

Dam failure events from abroad such as Malpasset/Vaiont in the 1960s led the UK government to revisit the 1930s Act in 1966 with many improvements suggested, most of which now sits within the current legislation as we know it. Other legislation followed, the Water Act 2003, the 2010 Flood and Water Management Act along with recommendations, such as the Pitt Report in 2007 have subsequently help shape reservoir safety legislation in the United Kingdom.

The jury at the inquest into the lives lost at Dolgarrog returned a verdict of 'accidental death', after hearing technical evidence from Sir Ralph Freeman. He claimed the flood had been 'caused by the bursting of the dam under the wall in consequence of the wall lacking a proper foundation' and that this foundation 'had not been sufficiently deep'.

Parliamentary records suggest 'the damage was done in the construction originally'.

The investigation led to improved construction requirements for dams in the United Kingdom, as part of the Reservoirs (Safety Provisions) Act in 1930. This required the owners of reservoirs with a capacity of more than 5 million gallons $\left(22700 \mathrm{~m}^{3}\right)$ above the natural level of any part of the surrounding ground, to provide for their inspection by a qualified civil engineer who was a member of a panel of civil engineers constituted for the purposes of the Act.

The Reservoirs Act 1975 went beyond the provisions of the earlier Act in a number of ways. Local authorities were designated as enforcement authorities, being required to keep registers of all raised reservoirs (defined as those with a capacity greater than $25000 \mathrm{~m}^{3}$ above the natural level of any part of the land adjoining the reservoir) and to ensure that undertakers, usually the owners, complied with the requirements of the Act. The duties of undertakers, enforcement authorities and engineers appointed to the various panels were laid down in the Act or set out in regulations.

\section{Remembering the lives lost}

By 1970 some vegetation had established on the site but the whole field was visible from the road as seen in Figures 2 and 3.

By the beginning of the new millennium, nature had claimed back the site as her own, with little or none of the boulder field visible from the road. So, in 2004 a $£ 60000$ memorial trail funded by the National Lottery was created by Walter Jones of Dolgarrog Community Council. It was officially opened by the last survivor of the dam disaster, Fred Brown who lost his mother and his younger sister in the disaster. It takes visitors to where the boulders washed down by the flood reside, these very boulders helped destroy the village buildings. The information boards along the path explain the tragic story to visitors.

In late 2016 a member of the British Dam Society, who stopped at the site to pay his respects, noticed the dilapidated state of the information boards and the overgrown appearance of the boulder field (Figure 4). He contacted Dr Andy 


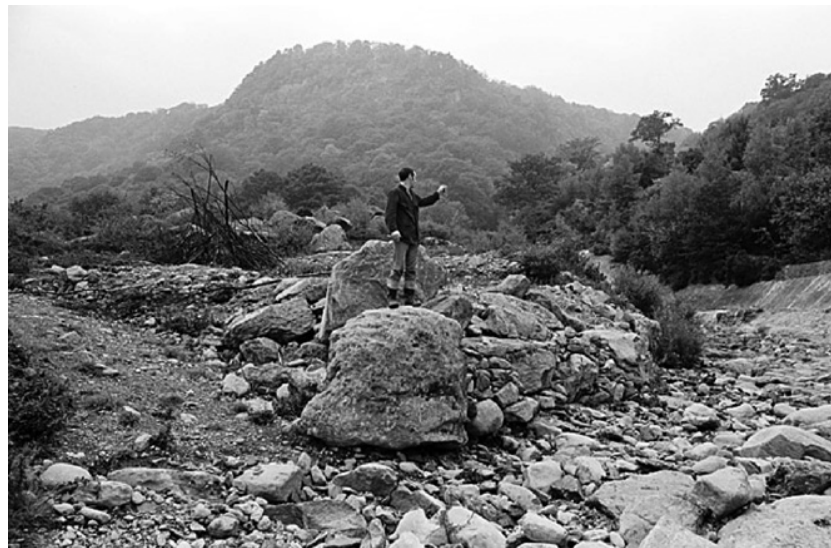

Figure 2. Dolgarrog site in 1970

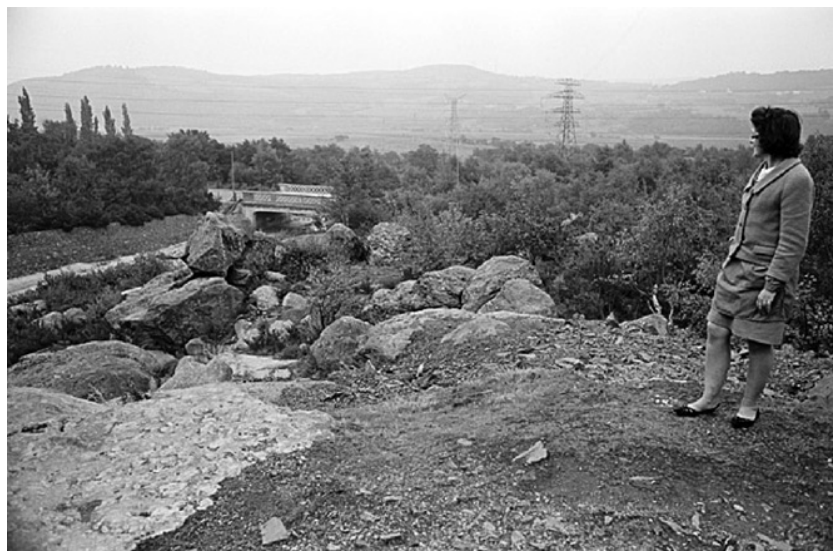

Figure 3. Dolgarrog site in 1970

Hughes, the then BDS chairman, and inquired whether BDS could do anything to help improve the site. Andy agreed that something must be done and secured funding of $£ 5000$ from BDS to carry out improvement and clearance works. At the same time he contacted Cllr Dafydd Williams, chairman of Dolgarrog Community Council who, by sheer coincidence, was in the process of securing lottery funding to replace the information boards and carry out some limited site improvement works, with the hope of completing the works prior to the 92nd anniversary of the disaster on 2 November 2017.

In early 2017, an informal partnership of interested parties was formed with Dolgarrog Community Council, consisting mainly of BDS, Natural Resources Wales, Dwr Cymru Welsh Water, Innogy and Severn Trent. The various organisations and companies agreed to provide the community council with financial contributions or project support, including the use of physical labour, technical expertise and access to suitable framework contractors.

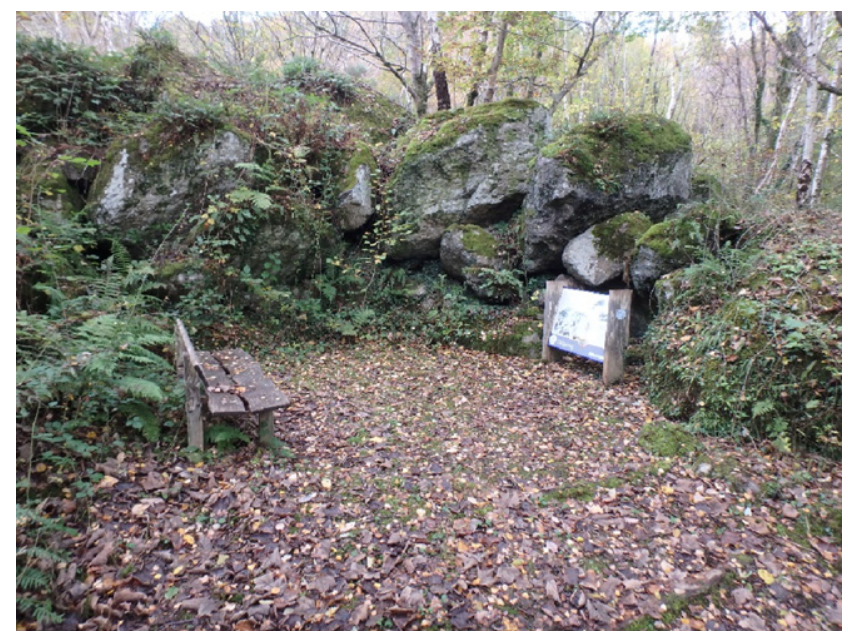

Figure 4. Memorial site in November 2016

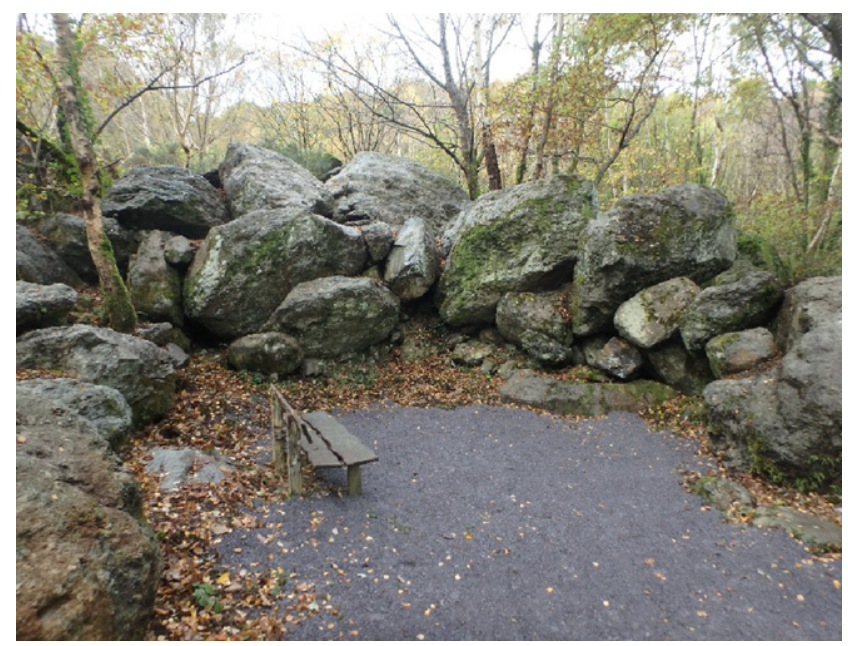

Figure 5. Memorial site in November 2017

Site works commenced in August 2017, utilising a local landscape artist/contractor, beginning with the removal of the former dilapidated memorial and information boards. A new display was constructed, comprising of railway sleepers and large rocks, forming a structure that echoes what remains of the breached Llyn Eigiau Dam, just over 3 miles further up the valley. Cobble stones and larger rocks were laid in the 'breach' area, signifying the flow of water and debris through the damaged dam. A memorial slate plaque, detailing the names of the ten adults and six children who lost their lives, has been fixed onto a new slate obelisk. Within the top of the obelisk a small bell has been placed, as a reminder of the church bell which was washed away during the disaster, which was later recovered several miles downstream and returned to the community. 


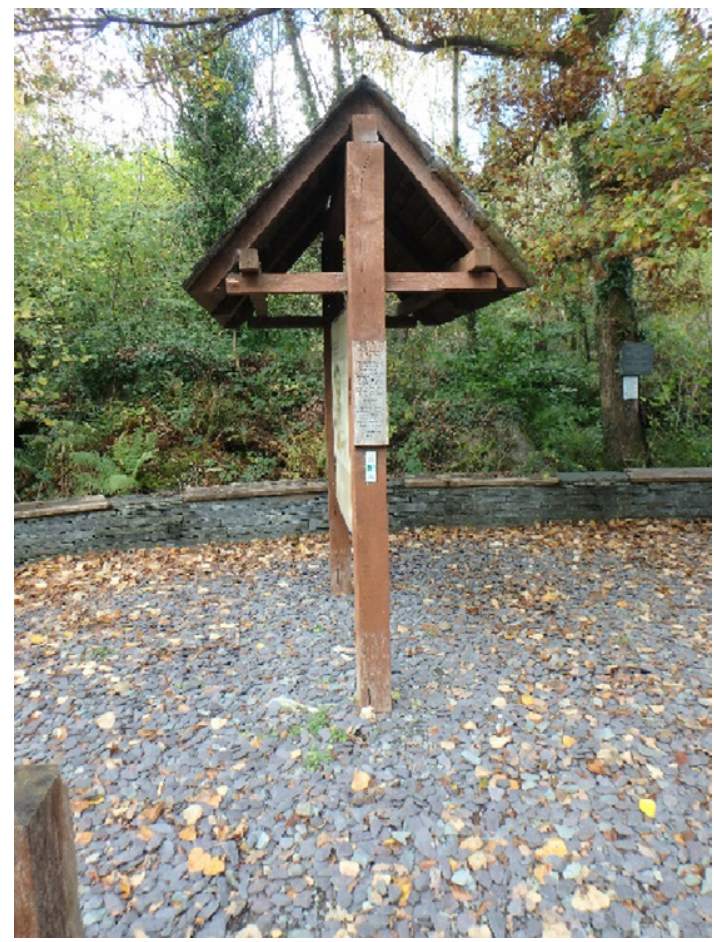

Figure 6. Information board in November 2016

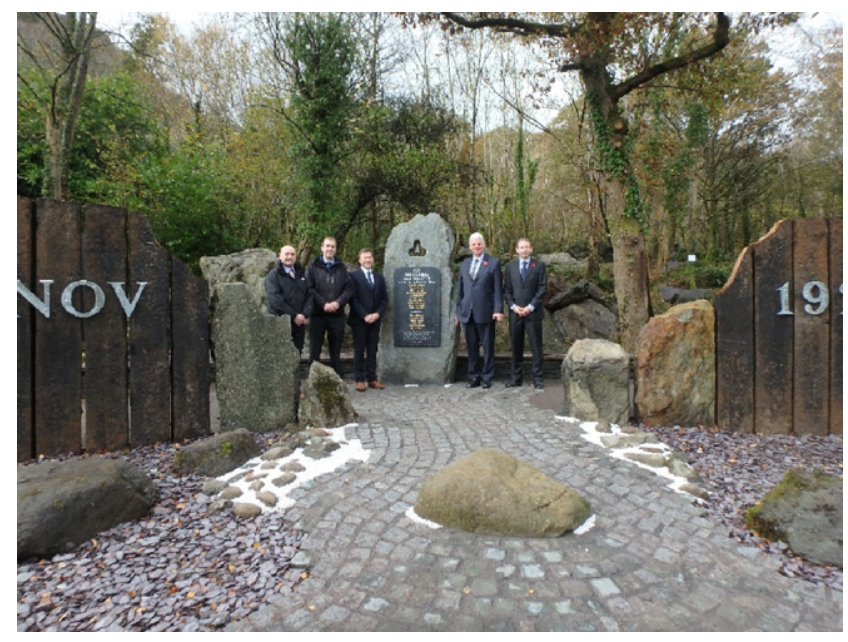

Figure 7. Ceremony on 2 November 2017

A local tree works contractor carried out several days of site clearance, including selective felling or thinning out of trees, removal of ivy growth from many of the boulders, which were deposited during the disaster and clearance of leaves and debris from the footpaths. Twenty tonnes of slate chippings was donated by a local haulage contractor, and volunteers from the community, Innogy and NRW

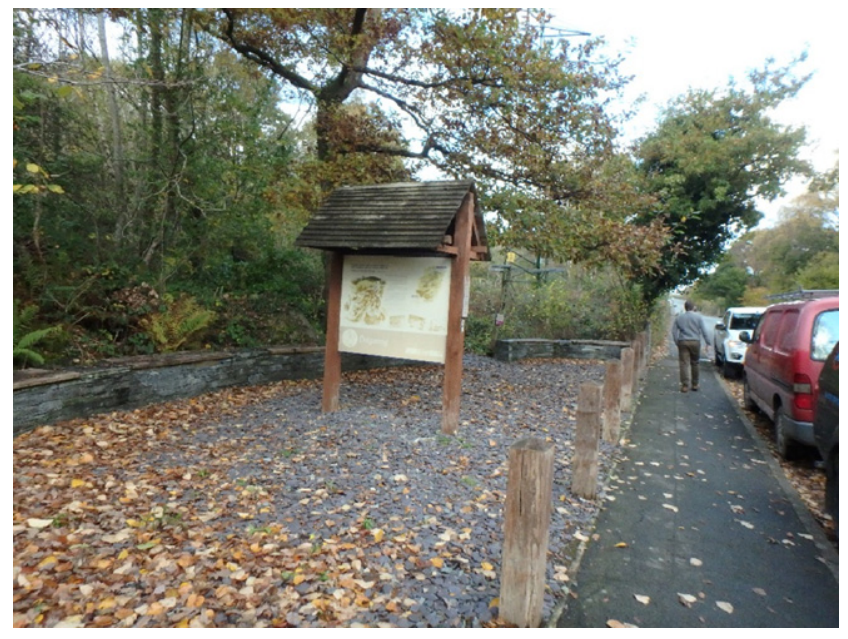

Figure 8. Information board in November 2016

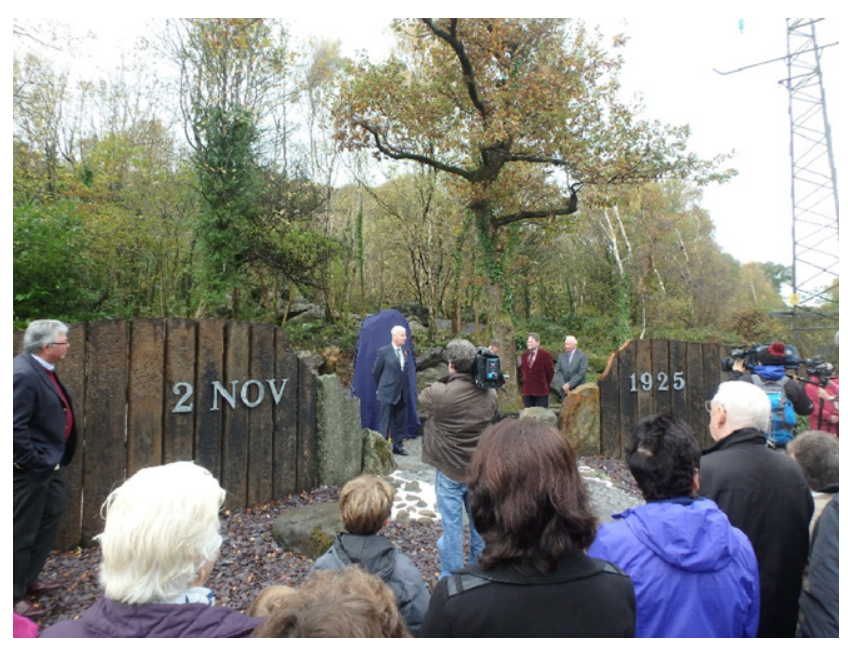

Figure 9. Opening ceremony on 2 November 2017

helped place the chippings on the footpaths within the boulder field.

An official ceremony was conducted on the 92nd anniversary of the disaster, on 2 November 2017, to bless the newly completed memorial structure and unveil the new slate plaque. Around a hundred local people and children attended, including television crews from BBC Wales News and the Welsh TV channel S4C. The local vicar read out the names of the victims and conducted the blessing ceremony. Speeches were given by a former resident who grew up in the village in the immediate years following the disaster, as well as some moving words given by Dr. Andy Hughes on the significance of the 1925 disaster and the importance of the site to the UK 
reservoir community and UK reservoir safety legislation. On the insistence of the community council, Dr. Andy Hughes was also given the honor of officially unveiling the new memorial plaque.

The Dolgarrog Community Council is very grateful and pleased with the assistance and support afforded to it by BDS and the other partners. Equally, the local community and residents and the UK reservoir community owe a debt of gratitude to the chairman of the council, Cllr Dafydd Williams, for his diligent (and voluntary) work over the years in keeping the memory of what occurred on the night of 2 November 1925, alive.

A selection of photos of the site prior to and on completion of the works is included in Figures 4-9.

\section{How can you contribute?}

To discuss this paper, please email up to 500 words to the editor at editor@britishdams.org. Your contribution will be forwarded to the author(s) for a reply and, if considered appropriate by the editorial board, it will be published as discussion in a future issue of the journal. 